チーグラー・ナッ夕触媒の発見から 30 余年を経て不 均一系触媒である $\mathrm{Mg}$ 担持 $\mathrm{Ti}$ 触媒の開発が一段落し た現在, 均一系チーグラー触媒が注目を集めている. 特に水と $\mathrm{AlMe}_{3}$ の反応で得られるメチルアルミノキ サン $\left(\mathrm{AlCH}_{3} \mathrm{O}\right)_{n}$ と有機遷移金属化合物からなる可 溶系の Kaminsky 触媒に関する研究が世界中で活発 に行われはじめた。その結果, 触媒の配位子を変える ことにより, 従来の固定概念を覆し, 可溶系でもアイ ソタクチック, あるいはシンジオタクチック重合の可 能なことがわかった ${ }^{11}$. なかでも，筆者らは，メチル アルミノキサンを用いた触媒系により, 高融点 $\left(270^{\circ} \mathrm{C}\right)$ かつ結晶化速度の速いシンジオタクチックポ リスチレン（rrう100\%）の合成に世界で初めて成功 した2). その後, シンジオタクチックポリスチレンに 関する多くの研究が報告され, しだいにその重合反応 の全貌が明らかになりつつある，以下に最近の結果を 中心に紹介する。

\section{i) 重合機構}

スチレンモノマーの挿入反応は, 重合初期の反応生 成物のガスクロマトグラフィーによる解析から, Secondary insertion であることが確認された。また，多 量のエチルベンゼンの副生が認められることから，ス チレン挿入後, $\beta$-水素脱離がおこって, 金属-水素結 合が形成され，この構造が活性点になると考えられて いる ${ }^{3)}$. NMR による反応生成物の解析でも同様の結 果が得られている4).さらに, 重水素化スチレンの共 重合の結果から，2 重結合の開鎖機構はシス開裂であ ることが結論されている5 。曾我ら ${ }^{6)}$ は，スチレンの 共重合の結果から，この重合反応は配位カチオン機構 であると推定している.

ii）ポリマー構造

ポリマー構造についても IR, X 線解析などにより 数多くの研究がなされ, 溶融後結晶化したサンプル （ $\alpha$-型結晶）は平面ジグザグ構造（図 1 a）を，また キャストフィルムから結晶化したサンプル $(\beta$-型結 晶）はラセン構造（図 $1 \mathrm{~b}$ ) を示すという興味深い結 果が報告されている。平面ジグザグ構造はラセン構造 より安定なため, $180^{\circ} \mathrm{C}$ 付近で $\beta$ 構造から $\alpha$ 構造へ の相転移が見られる7). また, Greis ら ${ }^{81}$ は, 3 本のポ リマー骨格が 1 つにまとまったクラスター構造の存在 を示唆する結果を得ている。

以上はシンジオタクチックポリスチレンについての 研究成果のほんの一部であり,まだまだ興味深い結果

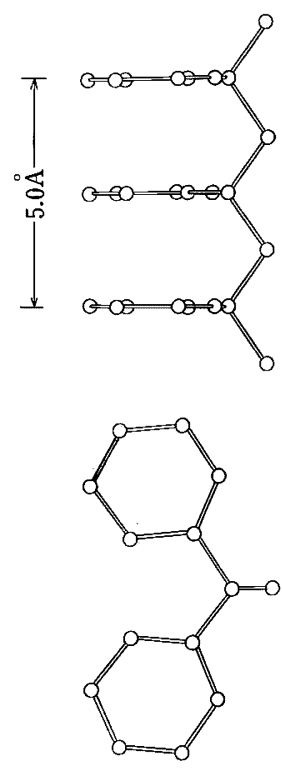

(a) $\alpha$-型結晶
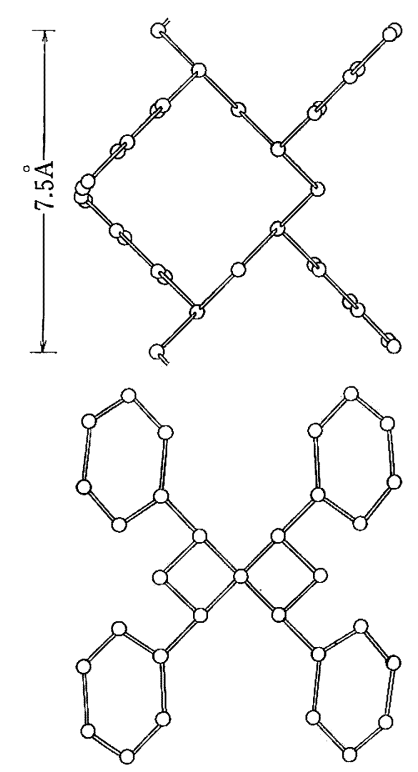

(b) $\beta$-型結晶
図 1 シンジオタクチックポリスチレンの分子構造

が沢山ある.さらに触媒の研究が進めば，ポリマーの 構造をより厳密に制御できる触媒の出現も夢ではない と確信している。

\section{文 献}

1) W. Kaminsky et al : Angew. Chem., 97, 507, (1985); J.A. Ewen: J. Am. Chem. Soc., 110, 6255 (1988)

2) N. Ishihara: Macromolecules, 19, 2464 (1986); 石原伸 英：高分子, 36 〔8〕604（1987）など

3) N. Ishihara: D. Phil. Thesis, Oxford 1990

4) A. Zambelli : Macromolecules, 20, 2035 (1987)

5) 三谷尚洋ら : 第 37 回高分子学会年会講演要旨集, 1152 (1988)

6) K. Soga et al.: Macromolecules, 23, 953 (1990)

7) M. Kobayashi et al.: ibid., 22, 4377 (1989)

8) O. Greis et al.: Polymer, 30, 590 (1989)

石原 伸英 Nobuhide Ishihara（出光興産 (株) 中央研究所-主任研究員, D. Phil., 専門=配位重合, 有機金属化学) 